\title{
A Survey of Disease Conditions in Sheep and Goats Slaughtered at Coimbatore District Slaughter House, Tamil Nadu, India
}

\author{
S.M. Dhishonin*, R. Narendra Babu, R. Ramani, K. Porteen, V. Appa Rao, \\ Robinson J.J. Abraham, R. Jayanthi and V. Govind \\ Department of Livestock Products Technology (Meat Science), Tamil Nadu Veterinary and \\ Animal Sciences University, Chennai-7, Tamil Nadu, India \\ *Corresponding author
}

\section{A B S T R A C T}

\section{Keywords}

Sheep and goat, Coimbatore, Cestodes.

\section{Article Info}

Accepted:

29 September 2017

Available Online:

10 October 2017
A Survey has been conducted to document different disease conditions encountered in sheep and goats slaughtered at Coimbatore district corporation slaughter house. Routine postmortem examination of a carcass was carried out as soon as possible after the completion of dressing in order to detect any abnormalities. 143 sheep and goat carcasses were identified as infected with parasitic and pathological conditions during postmortem inspection. Incidence of cestodes $14.02 \%$, Oestrus ovis $6.30 \%$, bruises $2.44 \%$, Lung lesion $5.89 \%$, Liver lesion $0.41 \%$. There was no significant difference $(\mathrm{P}>0.05)$ was noticed in parasitic and pathological conditions between male and female sheep but significant difference is there $(\mathrm{P}<0.05)$ in summer in Oestrus ovis. In summer 80 sheep and goat carcasses were identified as infected with parasitic and pathological conditions during postmortem inspection. Incidence of cestodes $17.00 \%$, amphistomes $8.91 \%$, Oestrus ovis $3.24 \%$, bruises $2.04 \%$, cysts $2.04 \%$ in sheep and goat carcasses. The pathological conditions observed in this are local lesions only not pertaining to a specific disease.

\section{Introduction}

Several diseases affecting livestock that causes serious effect on the production of animals, human health, trade of livestock and animal products, as a result the overall economic development will be affected (Depa et al., 2012). Improved quality and quantity of livestock products is necessary, in order to compete in the international market, which in turn needs disease free animal health status (Bhanuprakash et al., 2011). In recent times, emerging and re-emerging diseases of livestock, poultry and humans have tremendously increased. Many of the diseases like brucellosis, tuberculosis, glanders, influenza are of zoonotic significance (Kumar et al., 2015).

Recurring losses in productivity due to widely prevalent parasitic infection is important and common recurrent problem for small ruminant's production in most parts of the world.

Vast studies on the prevalence of GI parasites have been documented from different parts of India and a few numbers in Tamil Nadu. In addition to GI parasitic infection, small ruminants are also highly susceptible to 
haemoprotozoan parasites. The tropical environment is the major reason for the development of these parasitic diseases.

Besides economic losses, diseases of sheep and goats might constitute an epidemiological and zoonotic threat. As such problems concerning meat hygiene and possible health risks to the consumer should be documented during both ante mortem and post mortem examination. In this context, meat inspection data is a potential source of information and has an important role to play in quality meat production. A study was conducted to document the disease conditions encountered at Coimbatore district slaughter house of Tamil Nadu, India in both summer and winter seasons.

\section{Materials and Methods}

Routine postmortem examination of a carcass was carried out as soon as possible after the completion of dressing in order to detect any abnormalities. All organs and carcass portions were kept together and correlated for inspection before they were removed from the slaughter floor. During postmortem, liver and lung examination was conducted by visualization, palpation and incisions where necessary for the presence of cyst, parasites and other gross abnormalities. It was conducted based on the system wise i.e head and tongue, visceral organs from the thoracic cavity, abdominal cavity, pelvic cavity and the carcasses. Deep examination was conducted in lung, bronchi, rumen, abomasum, liver, bile duct and intestines for parasites. The affected organs are excised and were collected in the $10 \%$ formalin. The mesentery, heart, lung, liver was examined for any parasitic cysts. Pathological lesions were differentiated and judged according to guidelines on meat inspection for developing countries FAO. The samples like parasites and affected organs were collected for identification and further histopathological studies.

\section{Results and Discussion}

Coimbatore district is classified under zone 4 meat related variables zones. Corporation slaughter house is located at Ukkadam. The animals for slaughter are purchased by middle man procuring animals from Tharapuram, Kanniyapatti, Karur shandies and sometimes from Karnataka. Animals brought are rested for 8-12 hours prior to slaughter in lairage, facilitated with adequate floor space, ventilator and adequate water. The animals are slaughtered by halal method. Sheep breeds slaughtered are mainly Coimbatore, Trichy black, Nilagiri, Kilakarisal and nondescriptive sheep. The goat breeds slaughtered are Kanni adu, Salem black and Non descriptive goats.

\section{Winter season}

In winter the maximum temperature was $33^{\circ} \mathrm{C}$, and lowest temperature was $20^{\circ} \mathrm{C}$, and the mean temperature was $27^{\circ} \mathrm{C}$. The rainfall and humidity was $8.4 \mathrm{~mm}$ and $51 \%$ respectively. At Coimbatore slaughterhouse 356 sheep were examined, of which 296 were males and 60 were females. Apart from the above, 136 goats were examined, of which 114 were males and 22 were females.

A total of 492 animals (356 sheep and 136 goats) were examined for antemortem and postmortem inspection. Out of 492 animals none of them were showing any symptoms for contagious or infectious disease in antemortem inspection. 143 sheep and goat carcasses were identified as infected with parasitic and pathological conditions during postmortem inspection. Incidence of cestodes $14.02 \%$, Oestrus ovis $6.30 \%$, bruises $2.44 \%$, Lung lesion $5.89 \%$. Liver lesion $0.41 \%$ in sheep and goat carcasses are presented in Table 1. 


\section{Sex wise}

The analysis of data on the prevalence of parasitic and pathological conditions of male and female sheep in Coimbatore district for the winter season, showed an overall prevalence of cestodes $13.76 \%$ in male and $6.62 \%$ in female; Oestrus ovis $7.58 \%$ in male and $1.12 \%$ in female; Lung lesion $3.09 \%$ in male and $0.56 \%$ in female; Liver lesion $0.56 \%$ in male and $0 \%$ in female sheep respectively. There was no significant difference $(\mathrm{P}>0.05)$ was noticed in parasitic and pathological conditions between male and female sheep. The details are given in Table 2.

The analysis of data on the prevalence of parasitic and pathological conditions of male and female goat in Coimbatore district for the winter season, showed an overall prevalence of cestodes $6.62 \%$ in male and $1.47 \%$ in female; Lung lesion $8.82 \%$ in male and $2.94 \%$ in female; bruises $6.62 \%$ in male and $2.21 \%$ in female goat respectively. There was no significant difference $(\mathrm{P}>0.05)$ was observed in parasitic and pathological conditions between male and female goat. The details are given in Table 3. The results are contradictory to the results of Varadharajan and Vijayalakshmi (2015). They reported that at summer season the infection was $55.30 \%$.

\section{Species wise}

The analysis of data on the prevalence of parasitic and pathological conditions of sheep and goats in Coimbatore district for the winter season, showed an overall prevalence of cestodes $16.29 \%$ in sheep $8.08 \%$ in goat; Oestrus ovis $8.71 \%$ in sheep and $0 \%$ in goat; Lung lesion $3.65 \%$ in sheep and $11.76 \%$ in goat; Liver lesion $0.56 \%$ in sheep and $0 \%$ in goat; bruises $0 \%$ in sheep and $8.82 \%$ in goat respectively. There was high significant difference $(\mathrm{P}<0.01)$ observed in Oestrus ovis, Lung lesion and bruises between sheep and goat and significant difference $(\mathrm{P}<0.05)$ was observed in cestodes between sheep and goats. There was no significant difference $(\mathrm{P}>0.05)$ was noticed in other parasitic and pathological conditions between sheep and goats. The details are given in Table 4. More number of lung lesions observed in goats $(11.76 \%)$ and in sheep $(3.65 \%)$ in this study this might be due to susceptibility of goats to lower temperatures (Rahal et al., 2014) during winter in this area. There was no significant difference $(\mathrm{P}>0.05)$ observed in liver lesions between sheep and goats. Sheep had higher prevalence for cestodes and Oestrus ovis. Goats had the higher prevalence for the bruises and Lung lesions.

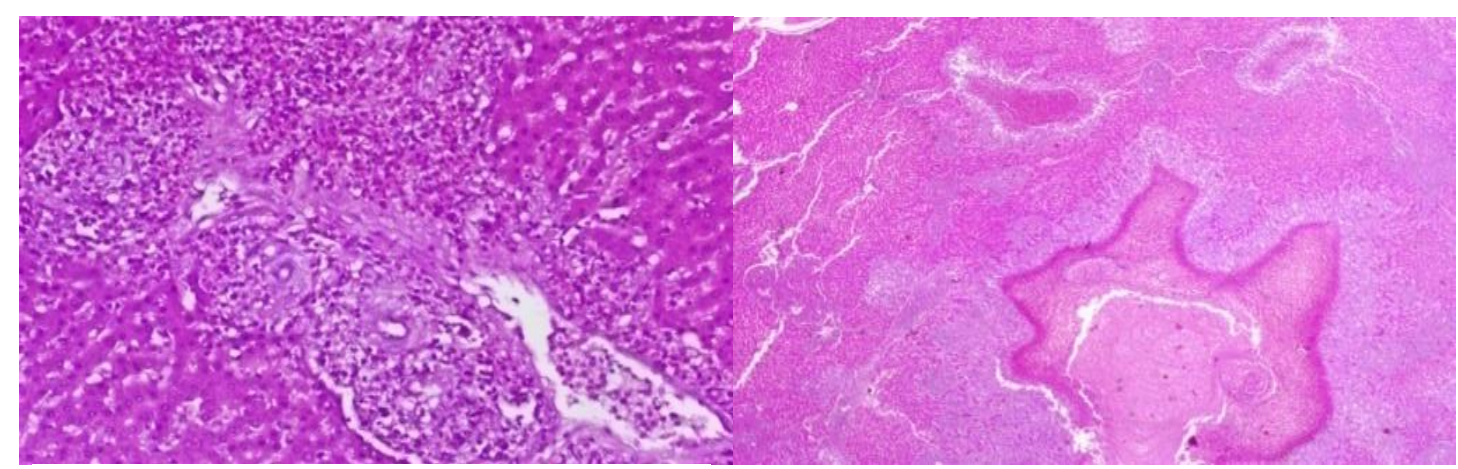

Plate.1 Multifocal periportal necrosis and hepatitis

Plate.2 Necrotic hepatitis 


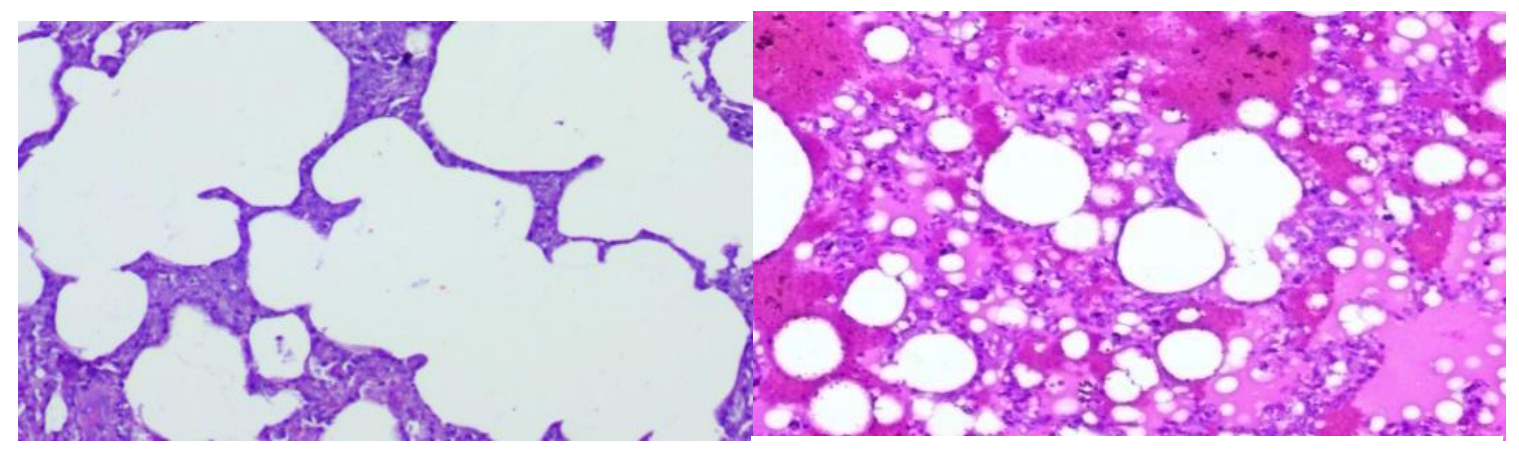

Plate.3 Emphysema

Plate.4 Pulmonary congestion and edema

Table.1 Number of carcasses affected in Coimbatore slaughterhouse in winter

\begin{tabular}{|l|l|l|l|l|}
\hline S. No. & Conditions & Affected carcass & $\begin{array}{l}\text { Healthy } \\
\text { carcass }\end{array}$ & $\begin{array}{l}\text { Total number of } \\
\text { carcasses inspected }\end{array}$ \\
\cline { 1 - 3 } 1. & Cestodes & $69(14.02 \%)$ & \multirow{2}{*}{349} & \multirow{2}{*}{492} \\
\cline { 1 - 3 } 2. & Oestrus ovis & $31(6.30 \%)$ & & \\
\cline { 1 - 3 } 3. & Bruises & $12(2.44 \%)$ & & \\
\cline { 1 - 3 } 5. & Lung lesions & $29(5.89 \%)$ & & \\
\hline
\end{tabular}

Table.2 Number of carcasses affected in Coimbatore slaughterhouse in summer

\begin{tabular}{|l|l|l|l|l|}
\hline S. No. & Conditions & Affected carcass & $\begin{array}{l}\text { Healthy } \\
\text { carcass }\end{array}$ & $\begin{array}{l}\text { Total number of } \\
\text { carcasses inspected }\end{array}$ \\
\cline { 1 - 3 } 1. & Cestodes & $42(17.00 \%)$ & & \multirow{2}{*}{167} \\
\cline { 1 - 2 } 2. & Amphistomes & $20(8.91 \%)$ & \multirow{2}{*}{247} \\
\cline { 1 - 3 } 3. & Oestrus ovis & $8(3.24 \%)$ & & \\
\cline { 1 - 2 } 5. & Bruises & $5(2.04 \%)$ & & \\
\hline & Cysts & $5(2.04 \%)$ & & \\
\hline
\end{tabular}




\section{Int.J.Curr.Microbiol.App.Sci (2017) 6(10): 3692-3699}

Table.3 Animals affected in Coimbatore slaughterhouse in winter - sex wise

\begin{tabular}{|c|c|c|c|c|c|c|c|c|c|c|c|c|c|c|c|c|}
\hline \multirow{3}{*}{\multicolumn{2}{|c|}{ Species }} & \multicolumn{15}{|c|}{ Conditions } \\
\hline & & \multicolumn{2}{|c|}{ Cestodes } & \multirow[b]{2}{*}{$\chi^{2}$} & \multicolumn{2}{|c|}{ Oestrus ovis } & \multirow[b]{2}{*}{$\chi^{2}$} & \multicolumn{2}{|c|}{ Lung lesion } & \multirow[b]{2}{*}{$\chi^{2}$} & \multicolumn{2}{|c|}{ Liver lesion } & \multirow[b]{2}{*}{$\chi^{2}$} & \multicolumn{2}{|c|}{ Bruises } & \multirow[b]{2}{*}{$\begin{array}{l}\chi \\
2\end{array}$} \\
\hline & & $\begin{array}{l}\text { Number } \\
\text { of } \\
\text { animals }\end{array}$ & $\%$ & & $\begin{array}{l}\text { Number } \\
\text { of } \\
\text { animals }\end{array}$ & $\%$ & & $\begin{array}{c}\text { Number } \\
\text { of } \\
\text { animals }\end{array}$ & $\%$ & & $\begin{array}{l}\text { Number } \\
\text { of } \\
\text { animals }\end{array}$ & $\%$ & & $\begin{array}{c}\text { Number } \\
\text { of } \\
\text { animals }\end{array}$ & $\%$ & \\
\hline \multirow{2}{*}{ Sheep } & $\mathrm{M}(296)$ & 49 & 13.76 & \multirow{2}{*}{$\begin{array}{c}0.09 \\
\text { NS }\end{array}$} & 27 & 7.58 & \multirow{2}{*}{$\begin{array}{c}0.30 \\
\mathrm{NS}\end{array}$} & 11 & 3.09 & \multirow{2}{*}{$\begin{array}{c}0.02 \\
\mathrm{NS}\end{array}$} & 2 & 0.56 & \multirow{2}{*}{$\begin{array}{c}0.41 \\
\mathrm{NS}\end{array}$} & 0 & 0 & \\
\hline & $\mathrm{F}(60)$ & 9 & 6.62 & & 4 & 1.12 & & 2 & 0.56 & & 0 & 0 & & 0 & 0 & \\
\hline \multirow{2}{*}{ Goat } & $\mathrm{M}(114)$ & 9 & 6.62 & \multirow{2}{*}{$\begin{array}{c}0.04 \\
\mathrm{NS}\end{array}$} & 0 & 0 & & 12 & 8.82 & \multirow{2}{*}{$\begin{array}{l}1.04 \\
\mathrm{NS}\end{array}$} & 0 & 0 & & 9 & 6.62 & \multirow{2}{*}{$\begin{array}{c}0.76 \\
\text { NS }\end{array}$} \\
\hline & $\mathrm{F}(22)$ & 2 & 1.47 & & 0 & 0 & & 4 & 2.94 & & 0 & 0 & & 3 & 2.21 & \\
\hline
\end{tabular}

NS= Not Significant

Table.4 Animals affected in Coimbatore slaughterhouse in winter - Species wise

\begin{tabular}{|c|c|c|c|c|c|c|c|c|c|c|c|c|c|c|c|}
\hline \multirow{2}{*}{ Species } & \multicolumn{15}{|c|}{ Conditions } \\
\hline & \multicolumn{2}{|c|}{ Cestodes } & $\chi^{2}$ & \multicolumn{2}{|c|}{ Oestrus ovis } & $\chi^{2}$ & \multicolumn{2}{|c|}{ Lung lesion } & $\chi^{2}$ & \multicolumn{2}{|c|}{ Liver lesion } & $\chi^{2}$ & \multicolumn{2}{|c|}{ Bruises } & $\chi^{2}$ \\
\hline
\end{tabular}

Cestodes: $\chi^{2}=(5.49)^{* ;}$ Oestrus ovis: $=(12.64)^{* * ;}$ Lung lesion: $\chi^{2}=(11.68)^{* * ;}$ Bruises: $=(32.20)^{* *}$

$* *=$ statistically highly significant at 1 percent level; $*=$ statistically significant at 5 percent level; NS $=$ Not Significant 
Table.5 Animals affected in Coimbatore slaughterhouse in summer- sexwise

\begin{tabular}{|c|c|c|c|c|c|c|c|c|c|c|c|c|c|c|c|c|}
\hline \multirow{3}{*}{\multicolumn{2}{|c|}{ Species }} & \multicolumn{15}{|c|}{ Conditions } \\
\hline & & \multicolumn{2}{|c|}{ Cestodes } & \multirow[b]{2}{*}{$\chi^{2}$} & \multicolumn{2}{|c|}{ Amphistomes } & \multirow[b]{2}{*}{$\chi^{2}$} & \multicolumn{2}{|c|}{ Oestrus ovis } & \multirow[b]{2}{*}{$\chi^{2}$} & \multicolumn{2}{|c|}{ Cysts } & \multirow[b]{2}{*}{$\chi^{2}$} & \multicolumn{2}{|c|}{ Bruises } & \multirow[b]{2}{*}{$\chi^{2}$} \\
\hline & & $\begin{array}{l}\text { Number } \\
\text { of } \\
\text { animals }\end{array}$ & $\%$ & & $\begin{array}{l}\text { Number } \\
\text { of } \\
\text { animals }\end{array}$ & $\%$ & & $\begin{array}{c}\text { Number } \\
\text { of } \\
\text { animals }\end{array}$ & $\%$ & & $\begin{array}{c}\text { Number } \\
\text { of } \\
\text { animals }\end{array}$ & $\%$ & & $\begin{array}{l}\text { Number } \\
\text { of } \\
\text { animals }\end{array}$ & $\%$ & \\
\hline \multirow{2}{*}{ Sheep } & $\mathrm{M}(148)$ & 25 & 13.97 & \multirow{2}{*}{$\begin{array}{c}0.56 \\
\mathrm{NS}\end{array}$} & 14 & 7.82 & \multirow{2}{*}{$\begin{array}{c}3.18 \\
\mathrm{NS}\end{array}$} & 4 & 2.29 & \multirow{2}{*}{$6.25 *$} & 3 & 1.68 & \multirow{2}{*}{$\begin{array}{c}0.17 \\
\mathrm{NS}\end{array}$} & 1 & 0.56 & \multirow{2}{*}{$\begin{array}{c}0.21 \\
\mathrm{NS}\end{array}$} \\
\hline & $\mathrm{F}(31)$ & 7 & 3.91 & & 0 & 0 & & 4 & 2.29 & & 1 & 0.56 & & 0 & 0 & \\
\hline \multirow{2}{*}{ Goat } & $\mathrm{M}(56)$ & 7 & 10.29 & \multirow{2}{*}{$\begin{array}{l}1.23 \\
\mathrm{NS}\end{array}$} & 5 & 7.35 & \multirow{2}{*}{$\begin{array}{c}0.00 \\
\mathrm{NS}\end{array}$} & 0 & 0 & & 1 & 1.47 & \multirow{2}{*}{$\begin{array}{c}0.22 \\
\mathrm{NS}\end{array}$} & 3 & 4.41 & \multirow{2}{*}{$\begin{array}{c}0.16 \\
\mathrm{NS}\end{array}$} \\
\hline & $\mathrm{F}(12)$ & 3 & 4.41 & & 1 & 1.47 & & 0 & 0 & & 0 & 0 & & 1 & 1.47 & \\
\hline
\end{tabular}

Oestrus ovis: $\chi^{2}=(6.25)^{* *}=$ statistically significant at 5 percent level; NS= Not Significant

Table.6 Animals affected in Coimbatore slaughterhouse in summer - Species wise

\begin{tabular}{|c|c|c|c|c|c|c|c|c|c|c|c|c|c|c|c|}
\hline \multirow{3}{*}{ Species } & \multicolumn{15}{|c|}{ Conditions } \\
\hline & \multicolumn{2}{|c|}{ Cestodes } & \multirow[b]{2}{*}{$\chi^{2}$} & \multicolumn{2}{|c|}{ Amphistomes } & \multirow[b]{2}{*}{$\chi^{2}$} & \multicolumn{2}{|c|}{ Oestrus ovis } & \multirow[b]{2}{*}{$\chi^{2}$} & \multicolumn{2}{|c|}{ Cysts } & \multirow[b]{2}{*}{$\chi^{2}$} & \multicolumn{2}{|c|}{ Bruises } & \multirow[b]{2}{*}{$\chi^{2}$} \\
\hline & $\begin{array}{c}\text { Number } \\
\text { of } \\
\text { animals }\end{array}$ & $\%$ & & $\begin{array}{c}\text { Number } \\
\text { of } \\
\text { animals }\end{array}$ & $\%$ & & $\begin{array}{l}\text { Number } \\
\text { of } \\
\text { animals }\end{array}$ & $\%$ & & $\begin{array}{c}\text { Number } \\
\text { of } \\
\text { animals }\end{array}$ & $\%$ & & $\begin{array}{c}\text { Number } \\
\text { of } \\
\text { animals }\end{array}$ & $\%$ & \\
\hline Sheep(179) & 32 & 17.88 & \multirow{2}{*}{$\begin{array}{c}0.35 \\
\text { NS }\end{array}$} & 14 & 7.82 & \multirow{2}{*}{$\begin{array}{c}0.07 \\
\text { NS }\end{array}$} & 8 & 4.70 & \multirow{2}{*}{$\begin{array}{r}3.14 \\
\mathrm{NS}\end{array}$} & 4 & 2.23 & \multirow{2}{*}{$\begin{array}{c}0.15 \\
\mathrm{NS}\end{array}$} & 1 & 0.56 & \multirow{2}{*}{$\begin{array}{c}7.04 \\
* *\end{array}$} \\
\hline Goat(68) & 10 & 14.71 & & 6 & 8.82 & & 0 & 0 & & 1 & 1.47 & & 4 & 5.88 & \\
\hline
\end{tabular}

Bruises: $\chi^{2}=(7.04)^{* * * *}=$ statistically highly significant at 1 percent level; NS= Not Significant 
Varadharajan and Vijayalakshmi (2015) also found higher incidence of cestodes in sheep than goat. Bruises in goats may be due to animal behaviour and improper handling and the reason for increased number may be due to unequal sample size. Regarding Oestrus ovis the results are in agreement with Shoorijeh et al., (2010). The results of their study clearly demonstrated that Oestrus ovis was significantly higher in sheep than goats.

\section{Summer}

In summer the maximum temperature was $35^{\circ} \mathrm{C}$, and lowest temperature was $24^{\circ} \mathrm{C}$, and the mean temperature was $29^{\circ} \mathrm{C}$. The rainfall and humidity was $62.2 \mathrm{~mm}$ and $68 \%$ respectively. At Coimbatore slaughterhouse 179 sheep were examined, of which 148 were males and 31 were females. Apart from the above, 68 goats were examined, of which 56 were males and 12 were females. A total of 247 animals (179 sheep and 68 goats) were examined for antemortem and postmortem inspection. Out of 492 animals none of them were showing any symptoms for contagious or infectious disease in antemortem inspection. 80 sheep and goat carcasses were identified as infected with parasitic and pathological conditions during postmortem inspection. Incidence of cestodes $17.00 \%$, amphistomes $8.91 \%$, Oestrus ovis $3.24 \%$, bruises $2.04 \%$, cysts $2.04 \%$ in sheep and goat carcasses are presented in Table 2.

\section{Sex wise}

The analysis of data on the prevalence of parasitic and pathological conditions of male and female sheep in Coimbatore district for the summer season, showed an overall prevalence of cestodes $13.97 \%$ in male and $3.91 \%$ in female; amphistomes $7.82 \%$ in male and $0 \%$ in female; Oestrus ovis $2.29 \%$ in male and $2.29 \%$ in female; cysts $1.68 \%$ in male and $0.56 \%$ in female; bruises $0.56 \%$ in male and $0 \%$ in female sheep respectively. There was significant difference $(\mathrm{P}<0.05)$ noticed in Oestrus ovis and no significant difference $(\mathrm{P}>0.05)$ was noticed in other parasitic and pathological conditions between male and female sheep. The details are given in Table 5.

The analysis of data on the prevalence of parasitic and pathological conditions of male and female goat in Coimbatore district for the summer season, showed an overall prevalence of cestodes $10.29 \%$ in male and $4.41 \%$ in female; amphistomes $7.35 \%$ in male and $1.47 \%$ in female; cysts $1.47 \%$ in male and $0 \%$ in female; bruises $4.41 \%$ in male and $1.47 \%$ in female goat respectively. There was no significant difference $(\mathrm{P}>0.05)$ was observed in parasitic and pathological conditions between male and female goat. The details are given in Table 5. The higher prevalence of infestation was noticed in both the sexes. The results are in agreement with Shoorijeh et al., (2010). The results of their study clearly demonstrated that Oestrus ovis was significantly higher in sheep than goats.

\section{Species wise}

The analysis of data on the prevalence of parasitic and pathological conditions of sheep and goats in Coimbatore district for the summer season, showed an overall prevalence of cestodes $17.88 \%$ in sheep $14.71 \%$ in goat; amphistomes $7.82 \%$ in sheep and $8.82 \%$ in goat; Oestrus ovis $4.70 \%$ in sheep and $0 \%$ in goat; cysts $2.23 \%$ in sheep and $1.47 \%$ in goat; bruises $0.56 \%$ in sheep and $5.88 \%$ in goat respectively. There was high significant difference $(\mathrm{P}<0.01)$ observed in bruises between sheep and goat and no significant difference $(\mathrm{P}>0.05)$ was noticed in other parasitic and pathological conditions between sheep and goats. The details are given in Table 6. There was a highly significant difference $(\mathrm{P}<0.01)$ was observed in case of goat. This may be due to animal behaviour and improper handling of animals and 
unequal animal size presented at the slaughter. Lung lesions observed in this study are emphysema, pulmonary congestion and edema. Liver lesions observed were multifocal periportal necrosis, Necrotic hepatitis.

The data collected was mostly from young animals meant for slaughter, so the incidence of diseases are less when compared to other reports and also there was no significant difference in disease conditions between the seasons in this study because the inspection was conducted only in the authorized slaughter houses. This indicates that farmers/ middleman/ butchers are aware of consumer safety and so only disease free animals are sent for slaughter in authorized slaughterhouse. It was also observed in this study that the animals presented for slaughter were properly dewormed and maintained by the farmers as per the demand of the processors for disease free animals.

\section{Acknowledgement}

This manuscript forms part of thesis submitted by the first author to Tamil nadu Veterinary and Animal Sciences University.

\section{References}

Bhanuprakash, V., G. Venkatesan., V. Balamurugan., M. Hosamani., R.
Yogisharadhya., R. S. Chauhan., A. Pande., B. Mondal, and R. K. Singh, 2010. Pox outbreaks in Sheep and Goats at Makhdoom (Uttar Pradesh), India: Evidence of Sheep pox Virus Infection in Goats. Transbound Emerg Dis. 57: 375-382.

Depa, P.M., U. Dimri, M.C. Sharma, and R. Tiwari, 2012. Update on epidemiology and control of Foot and Mouth Disease - A menace to international trade and global animal enterprise. Vet. World, 5: 694-704.

Kumar, R., S.P. Singh, and C.V., Savalia, 2015. Overview of Emerging Zoonoses in India: Areas of Concern. J Trop Dis., 3: 165.

Rahal, A., Ahmad, A.H., Prakash, A., Mandil, R. and Kumar, A.T., 2014. Environmental attributes to respiratory diseases of small ruminants. Veterinary Medicine International, 2014.

Shoorijeh, S.J., A. Tamadon., S. Negahban., M.A. Behzadi, and S.M. Biglari, 2010. Seasonal infection rates of Oestrus ovis. Online J. Vet Res., 14(2) : 302-310.

Varadharajan, A., and R. Vijayalakshmi."Prevalence and seasonal occurrence of gastrointestinal parasites in small ruminants of coastal areas of Tamil Nadu." J. Vet. Parasitol 17 159160.

\section{How to cite this article:}

Dhishonin, S.M., R. Narendra Babu, R. Ramani, K. Porteen, V. Appa Rao, Robinson J.J. Abraham, R. Jayanthi and Govind, V. 2017. A Survey of Disease Conditions in Sheep and Goats Slaughtered at Coimbatore District Slaughter House, Tamil Nadu, India. Int.J.Curr.Microbiol.App.Sci. 6(10): 3692-3699. doi: https://doi.org/10.20546/ijcmas.2017.610.433 